\title{
Evil Eye and Magic Plants in the Arribes del Duero (Salamanca-Zamora, Spain): A Review of the Literature ${ }^{1}$
}

\author{
Mal de ojo y plantas mágicas en Los Arribes del \\ Duero (Salamanca-Zamora, España): \\ una revisión bibliográfica
}

\author{
José Antonio González, \\ Mónica García-Barriuso y \\ Francisco Amich \\ Universidad de Salamanca
}

RESUMEN

Se ha llevado a cabo una revisión bibliográfica exhaustiva, relativa a la existencia de remedios vegetales contra el mal de ojo en el territorio de Los Arribes del Duero. Situada en el extremo centro-occidental de España, concretamente en el oeste de las provincias de Salamanca y Zamora, esta comarca ha sido una zona muy aislada hasta el siglo xx. Un total de 20 plantas vasculares son mencionadas en las obras consultadas. Los remedios preventivos tienen especial relación con momentos clave del calendario religioso. El Domingo de Ramos se bendicen ramos confeccionados con olivo, laurel y/o romero, que posteriormente se colocan en ventanas y balcones para proteger las casas, y durante la celebración de la hoguera de San Juan se queman plantas aromáticas. Asimismo, se recoge el uso tradicional de plantas repelentes de las brujas, plantas que son colgadas detrás de las puertas de casas y cuadras, y de rituales de curación de personas, animales, e incluso determinadas posesiones.

Palabras clave: Mal de ojo, Brujas, Remedios vegetales, Arribes del Duero, España.

\section{SUMMARY}

We performed a review of the literature referring to the existence of plant remedies against the evil eye in the Arribes del Duero (western part of the provinces of Salamanca and Zamora, CW Spain), an area very isolated up to the mid-twentieth century. A total

${ }^{1}$ This work forms part of an ethnobotanical research carried out in the Arribes del Duero by the participating group of the University of Salamanca (Spain) in "Red Iberoamericana de Saberes y Prácticas Locales sobre el Entorno Vegetal" (RISAPRET, CYTED). 
of 20 vascular plant species are mentioned. The preventive remedies are in particular associated with key moments in the religious calendar. On Palm Sunday, bunches made of olive tree, laurel and/or rosemary are blessed and then placed on window sills to protect people's homes, and during the celebration of St. John's Bonfire aromatic plants are burned. The traditional use of plants to repel witches, such as those plants being hung behind the doors of houses and stables, and the rituals for curing people, animals and even possessions were also compiled.

Key words: Evil Eye, Witches, Plant Remedies, Arribes del Duero, Spain.

\section{INTRODUCTION}

Belief in the existence of witches and in the mal de ojo (evil eye), is still deeply rooted in one sector of the Spanish population, which is highly specific as regards age and cultural level (people with basic studies and more than 70 years) (e.g. Baer et al. 2006: passim). This is more evident in rural areas of western Spain - Galicia, Asturias, W Castile and Leon, Extremadura, W Andalusia- (e.g. Fernández Álvarez and Breaux 1998: passim; Vallejo et al. 2008: passim). In the central-western part, the territory known as the Arribes del Duero (western part of the provinces of Salamanca and Zamora, Fig. 1), an area removed from others and very isolated up to the mid-twentieth century (Morán 1946: 138; Pascual 2009: 39), is a good example. In this interesting area, the collective memory of the inhabitants has a strong and deep-set recall of witches (Panero 2005: 114-120; Blanco 2009: 50; González 2010: passim). There are still stories of witches and "zánganos" (lit. drone bees, the name given to wizards or witches' assistants), of covens, of aquelarres, of the metamorphosis of witches into different guises, and of preventive and curative formulas against the evil eye.

The witches of the Arribes del Duero region have been identified, and indeed still are, as simple poor women from villages, hunched and ugly, who used not to be allowed to kiss children or enter people's houses or stables because it was crucial to avoid their influence and the malefic effect of the evil eye. In popular belief, asocial conduct is recorded as a characteristic trait of witches; they are rancorous and vengeful. They are also known to be able to shape-change at will, mainly into animals but also into whirlwinds (Blanco 1992: 59-77; Panero 2005: 113; González 2010: passim). All these features and the existence of stories about the stealing, mistreatment, and murder of newborn babies directly link the Arribes witches with the witch figure in Early Modern Spain (see Campagne 2008: passim).

Belief in the evil eye is one of the most extensive superstitions, not only in the Arribes del Duero area but throughout the province of Salamanca (Blanco 1985: 47-48). Defining the evil eye, within the sphere of this study, 


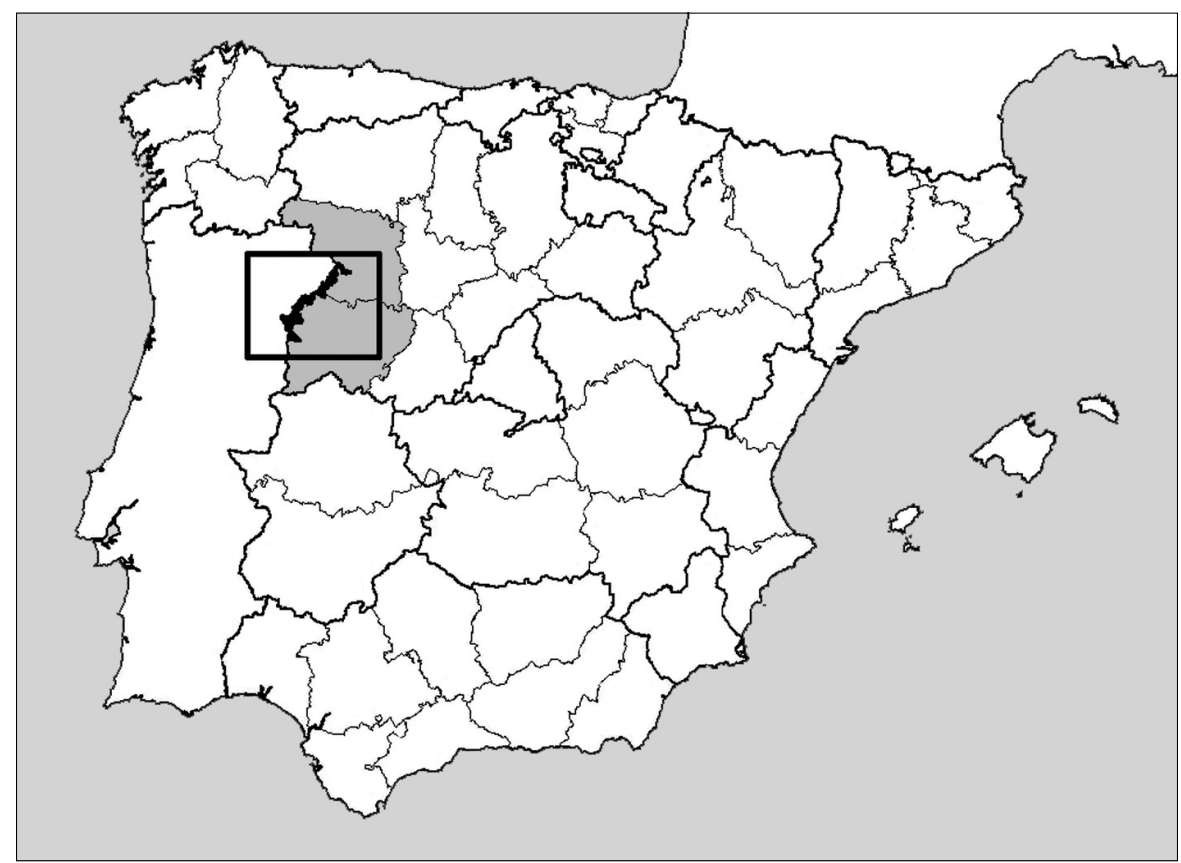

FIgURE 1: Geographic location of the Arribes del Duero area. The edge of the provinces of Salamanca and Zamora is shaded.

as a negative influence of magical or supernatural nature exerted by some people (in particular witches) on others just by looking at them (Blanco 1992: 106), is claimed to be produced voluntarily or involuntarily by certain people whose "look" has this innate quality (Narros 1951: 3). Among other malefic consequences, the evil eye affects both the peace of families and above all peoples' health (Fernández de Gatta 1951). Through jealousy, excessive praise and, in particular envy, children who have been affected by the evil eye for no apparent cause do not sleep or eat, fail to thrive, cry a lot, and may get sick and even die. In the case of pregnant women, it may cause them to miscarry and it may cause the mothers' milk to dry up. With respect to animals, these lose their appetites and may die suddenly; mothers abandon their young or may not allow them to suckle and they may even kill their offspring violently. The traditional matanza (slaughter of swine and preparation of hams and sausages, etc, for later curing) may fail, as may crops, and an interminable series of other malefic effects against people, animals or possessions may also materialize (Panero 2005: 113-120). 


\section{METHODOLOGY}

We performed a review of the large body of literature referring to the existence of plant remedies against witches and the evil eye in the Arribes del Duero area in the recent past.

As most references do not mention the scientific names of the plants, we performed investigations through interviews with the elderly inhabitants of the corresponding localities in order to identify them. Between 2005 and 2009, 116 semi-structured interviews were carried out with 80 non-specialist people ( 44 men and 36 women; mean age, 72), as part of an ethnobotanical research carried out in the area (e.g. González et al. 2010: 345). Regarding the taxonomy and nomenclature of the plants, we followed the "Flora iberica" (Castroviejo 1986-2010) for the families included therein and the "Flora Europaea" (Tutin et al. 1964-1993) for the remaining ones. Voucher specimens are deposited at SALA (the Herbarium of the University of Salamanca, Spain). In the case of some species, for which no voucher is available, a digital photograph number is included.

\section{RESULTS AND DISCUSSION}

Most of the rituals found were Catholic religious remedies. Thus, holy water, so entrenched in religious rites, was undoubtedly the preventive and curative remedy most widely used in all villages of the Arribes del Duero. On Holy Saturday (also known as the Saturday of Glory) it was collected from the church and kept in people's homes. The rooms, sick people or animals were sprinkled and blessed to protect them (Blanco 1985: 48; Panero 2005: 123).

As a preventive measure, even today in some villages the villagers hang scapulars (small bags, generally heart-shaped) around the necks of children or pin them to their clothes. These bags contain papers with the beginning of the Gospel of St. John, or the Regula Sancti Benedicti (Panero 2005: 121122). Also popular amulets are the scapulars of Our Lady of Mount Carmel and the Caravaca Cross (Blanco 1992: 136-140; Panero 2005: 122). Formerly, the children often used to wear a bag around their necks that contained a piece of piedra de ara (altar stone). Mothers would also place open scissors (to form a cross) under their children's pillows (Panero 2005: 122). A popular means to escape the possible consequences of getting too close to someone considered to be a witch was to recite the spell "Sábado boy, domingo mañana" (lit. Saturday today, Sunday tomorrow) (Hernández 1953), and everywhere can see crosses carved in stone or made of wood and placed on doors of houses and stables (Fig. 2). 
References can also be found to the use of amulets of a profane nature. Thus, to ward off the evil eye, some people wear even today protective amulets made with a badger's or rabbit's foot or a piece of azabache (jet) with the shape of a horn or a hand with the thumb between the index and second fingers (biga) (Blanco 1992: 109; Panero 2005: 123).

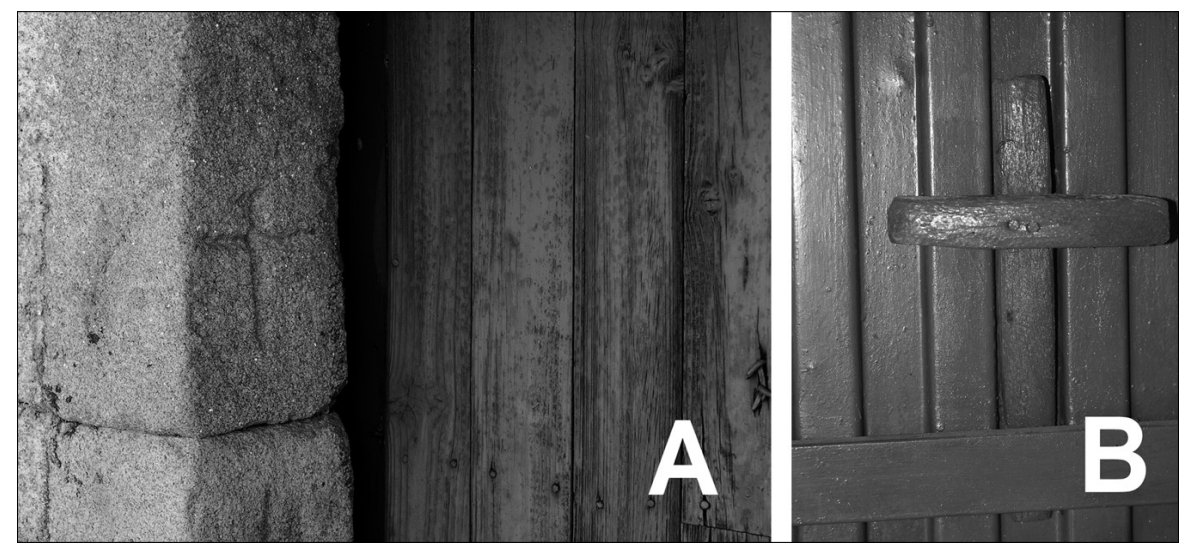

Figure 2: A. Cross carved in a door jamb. B. Cross made of wood and placed in the door of a stable.

Regarding the use of plants, there are many remedies to be found in the literature that are based on the use of "magic plants" (sensu Verde et al. 1997: 143-144). A total of 20 plant species were reported (see the Table). Eclectic pagan and religious practices are also common. For example, in Formariz (province of Zamora) three ears of rye (Secale cereale) or of wheat (Triticum aestivum) are moistened with holy water and are then used to bless a sick person or animal (Panero 2005: 126). At Villarino de los Aires (Salamanca), an ancient way of curing and protecting children was to throw four garbanzos (chick peas, seeds of Cicer arietinum) into the well (no longer present) of a certain church in the village (Morán 1927: 257). However, the sabumerios (the smoke produced by burning aromatic material to sabumar, from the Latin suffumre to smoke, to provide aromatic smoke to purify or merely produce a good smell —Dictionary of the Spanish Language, RAE 2010-) have been the most popular traditional method to ward of witches (Blanco 1992: 164-165; Panero 2005: 127). Years ago, in Fornillos de Fermoselle (Zamora) a bumaza (bonfire) was made with three aromatic plants on the eve of St. John: tomillo blanco (Thymus mastichina), tomillo sansero (T. zygis) and caña de San Juan (Magydaris panacifolia). Although 
these bonfires were not very large, they should produce as much smoke (with a penetrating odour) as possible for purifying people and their houses (Gallego and Gallego 2008: 81). In Gamones and Villardiegua (Zamora) stories are told about the recovery of children after they had been subjected to such practices: in particular after they had been "smoked" three times with the "blessed thymes" (Thymus mastichina, T. zygis and Lavandula pedunculata), which were collected from the procession on Corpus Christi (Panero 2005: 118-119). In Masueco (Salamanca), only tomillo de San Juan (Thymus mastichina) is used for the bonfire, which is lit on the eve of St. John (Blanco 1992: 164).

TABLE

\begin{tabular}{|c|c|c|c|c|c|c|c|}
\hline \multirow{2}{*}{$\begin{array}{l}\text { Species (botanical family) } \\
\text { Voucher }\end{array}$} & \multirow[t]{2}{*}{ Local name(s) } & \multirow[t]{2}{*}{ Status } & \multirow[t]{2}{*}{ Part(s) used } & \multicolumn{3}{|c|}{ Use-categories } & \multirow[t]{2}{*}{ Current use } \\
\hline & & & & Pro-PA & Pro-HS & Cur-PA & \\
\hline $\begin{array}{l}\text { Allium sativum L. (Liliaceae) } \\
\text { PHO } 103\end{array}$ & Ajo & $\mathrm{C}$ & $\begin{array}{l}\text { Bulbs and } \\
\text { string }\end{array}$ & & $\bullet$ & $\bullet$ & Yes \\
\hline $\begin{array}{l}\text { Cicer arietinum L. (Fabaceae) } \\
\text { PHO } 113\end{array}$ & Garbanzo & $\mathrm{C}$ & Seeds (dried) & $\bullet$ & & $\bullet$ & No \\
\hline $\begin{array}{l}\text { Dracunculus vulgaris Schott } \\
\text { in Schott \& Endl. (Araceae) } \\
\text { PHO } 156\end{array}$ & $\begin{array}{l}\text { Argontía, dragontía, } \\
\text { traguntía, organtía, } \\
\text { serpentaria }\end{array}$ & $\mathrm{C}$ & $\begin{array}{l}\text { Whole plant or } \\
\text { stems }\end{array}$ & & $\bullet$ & $\bullet$ & Yes \\
\hline $\begin{array}{l}\text { Laurus nobilis L. (Lauraceae) } \\
\text { PHO } 79\end{array}$ & Laurel, aurel & $\mathrm{C}, \mathrm{SD}$ & $\begin{array}{l}\text { Branches and } \\
\text { leaves }\end{array}$ & & $\bullet$ & & Yes \\
\hline $\begin{array}{l}\text { Lavandula pedunculata (Mill.) } \\
\text { Cav. (Lamiaceae) SALA } \\
17753\end{array}$ & $\begin{array}{l}\text { Tomillo, tomillo } \\
\text { moro, cantueso }\end{array}$ & W & $\begin{array}{l}\text { Flowered } \\
\text { aerial part }\end{array}$ & & & $\bullet$ & Yes \\
\hline $\begin{array}{l}\text { Magydaris panacifolia (Vahl) } \\
\text { Lange in Willk. \& Lange } \\
\text { (Apiaceae) SALA } 18297\end{array}$ & Caña de San Juan & W & $\begin{array}{l}\text { Flowered } \\
\text { aerial part }\end{array}$ & $\bullet$ & & $\bullet$ & Yes \\
\hline $\begin{array}{l}\text { Olea europaea L. (Oleaceae) } \\
\text { SALA } 17872\end{array}$ & Olivo, oliva & $\mathrm{C}(\mathrm{W})$ & $\begin{array}{l}\text { Branches and } \\
\text { leaves }\end{array}$ & $\bullet$ & $\bullet$ & $\bullet$ & Yes \\
\hline $\begin{array}{l}\text { Peucedanum officinale L. } \\
\text { (Apiaceae) SALA } 18348\end{array}$ & $\begin{array}{l}\text { Hierbatú, hierba tú, } \\
\text { hierba tul }\end{array}$ & W & Leaves & $\bullet$ & $\bullet$ & $\bullet$ & No \\
\hline $\begin{array}{l}\text { Rosmarinus officinalis L. } \\
\text { (Lamiaceae) SALA } 16225\end{array}$ & Romero & $\mathrm{C}, \mathrm{SD}$ & $\begin{array}{l}\text { Branches and } \\
\text { leaves }\end{array}$ & & $\bullet$ & & Yes \\
\hline $\begin{array}{l}\text { Ruta montana (L.) L. } \\
\text { (Rutaceae) SALA } 17983\end{array}$ & Ruda & W & $\begin{array}{l}\text { Flowered } \\
\text { aerial part }\end{array}$ & $\bullet$ & $\bullet$ & $\bullet$ & Yes \\
\hline $\begin{array}{l}\text { Scrophularia canina L. } \\
\text { (Scrophulariaceae) SALA } \\
69621\end{array}$ & $\begin{array}{l}\text { Hierba del mal de } \\
\text { ojo, maldeojo }\end{array}$ & W & Aerial part & & & $\bullet$ & No \\
\hline $\begin{array}{l}\text { Secale cereale L. (Poaceae) } \\
\text { PHO } 92\end{array}$ & Centeno & $\mathrm{C}$ & Ears & & & $\bullet$ & Yes \\
\hline $\begin{array}{l}\text { Sisymbrium officinale (L.) } \\
\text { Scop. (Brassicaceae) SALA } \\
18658\end{array}$ & Anda tú & W & Whole plant & & $\bullet$ & & No \\
\hline $\begin{array}{l}\text { Thymus mastichina (L.) L. } \\
\text { (Lamiaceae) SALA } 17736\end{array}$ & $\begin{array}{l}\text { Tomillo blanco, } \\
\text { tomillo de San } \\
\text { Juan, senserina, } \\
\text { alegría }\end{array}$ & W & $\begin{array}{l}\text { Flowered } \\
\text { aerial part }\end{array}$ & $\bullet$ & & $\bullet$ & Yes \\
\hline $\begin{array}{l}\text { Thymus zygis Loefl. ex L. } \\
\text { (Lamiaceae) SALA } 17737\end{array}$ & $\begin{array}{l}\text { Tomillo sansero, } \\
\text { senserino }\end{array}$ & W & $\begin{array}{l}\text { Flowered } \\
\text { aerial part }\end{array}$ & $\bullet$ & & $\bullet$ & No \\
\hline $\begin{array}{l}\text { Triticum aestivum } \mathrm{L} . \\
\text { (Poaceae) PHO } 91\end{array}$ & Trigo & $\mathrm{C}$ & Ears & & & $\bullet$ & Yes \\
\hline $\begin{array}{l}\text { Urginea maritima (L.) Baker } \\
\text { (Liliaceae) SALA } 15664\end{array}$ & Cebolla chirle & W & Bulbs & & & $\bullet$ & No \\
\hline $\begin{array}{l}\text { Verbascum pulverulentum } \\
\text { Vill. (Scrophulariaceae) } \\
\text { PHO } 44\end{array}$ & Gordolobo & W & $\begin{array}{l}\text { Flowered } \\
\text { aerial part }\end{array}$ & & & $\bullet$ & No \\
\hline $\begin{array}{l}\text { Verbena officinalis L. } \\
\text { (Verbenaceae) SALA } 16734\end{array}$ & Verbena & W & Flowers & & & $\bullet$ & No \\
\hline - & Candorga & - & Flowers & & & $\bullet$ & No \\
\hline
\end{tabular}

List of plant species used against the evil eye in the Arribes del Duero (W Spain). Voucher: SALA = voucher in Herbarium SALA; $\mathrm{PHO}=$ digital photograph. Status: $\mathrm{W}=$ wild (including naturalized); $\mathrm{C}=$ cultivated; $\mathrm{SD}=$ semi-domesticated (cultivated and reverted to wild status, and neglected cultivated plants). Use-categories: Pro-PA $=$ protection of people and/or animals; Pro-HS $=$ protection of houses and/or stables; Cur-PA $=$ curing of people and $/$ or animals . 
Other sabumerios were more sophisticated and used non-aromatic plants, such as the case described in Zamora by Panero (2005: 127), a sabumerio in which Lavandula pedunculata and Thymus zygis, pieces of Dracunculus vulgaris stems and strings of garlic (Allium sativum) were used. Halfway through the last century the parish priest of Villarino de los Aires (Salamanca) -D. Juan Manuel Hernández- explored popular beliefs in witches, and reports a sabumerio in which hierba del mal de ojo (lit. evil-eye herb, Scrophularia canina), cañas de San Juan (Magydaris panacifolia) and three olive leaves (Olea europaea) were used for protection (Hernández 1953). Likewise, Cortés Vázquez (1955: 16) report curing by means of a smoking mixture composed of small pieces of the cañas together with an herb called maldeojo, three olive leaves, three grains of rough salt, and three drops of oil. On the other hand, the Augustinian priest César Morán at Hinojosa de Duero (Salamanca) (Morán 1927: 253), claimed that people cure the evil eye with a plant called hierba tul (Peucedanum officinale) and reported another complex sabumerio in which children were cured passing them three times through a smoke achieved with a mixture of a small piece of a religious stole, feathers of pitorra (woodcock, a species that winters in the area), hedgehog teeth, wheat or rye straw, flowers of Verbena officinalis, rue (Ruta), cebolla chirle (bulbs of Urginea maritima), gordolobo (Verbascum pulverulentum), and flowers of candorga (?). None of the people we interviewed in this village knew this plant name. According to José de Lamano (1915: 317) and the Dictionary of the Spanish Language (RAE 2010) it is a rupicolous plant with long fleshy leaves used in the Arribes del Duero against witches' spells. Women who believe they are being pursued by witches put the plant in their shirts, close to the waist, close to the belly. In light of these data, we believe that it could correspond to Umbilicus heylandianus (Crassulaceae) or Digitalis thapsi (Scrophulariaceae).

Nevertheless, despite the above-described knowledge for curing the evil eye, the traditional culture of the Arribes del Duero seems to have preferred prevent than cure this fatal condition. Traditional prophylactic procedures were manifold and their efficiency against all kinds of negative effects was unquestioned, although special attention was always paid to witches. Thus, among the preventive remedies of religious nature, there are certain ligneous species that reflect back the power of witches because they have been blessed. These are the "ramos benditos" (blessed bunches); i.e. bunches that are blessed on Palm Sunday. They are placed on windowsills, balconies or on doors, and their use is triple; they bring luck, protect the home against lightning, and ward off the evil eye from the home and stables (Granzow de la Cerda 1993: 116; Gallego and Gallego 2008: 76). In Spain, the variety of species used is directly related to the flora of each region or district (e.g. 
Verde et al. 1997: 151; Pardo de Santayana 2008: 399-400). In the Arribes del Duero, the inhabitants use olive tree (Olea europaea), laurel (Laurus nobilis) and rosemary (Rosmarinus officinalis), either alone or combined (Fig. 3) (Blanco 1985: 48; Gallego and Gallego 2008: 77).
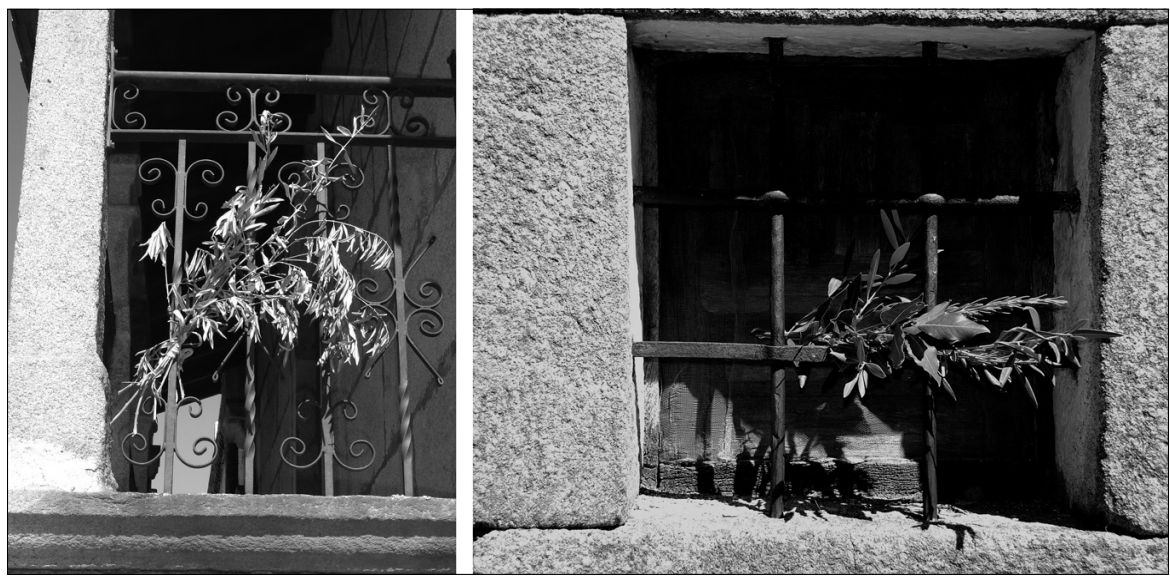

FIGURE 3: Palm Sunday blessed bunches made with branches of olive tree, laurel and/or rosemary placed in balconies and windows of the houses.

Regarding profane or non-religious remedies, evil eye repellents of plant origin are usually based on characteristics such as smell, as is the case of rue (Ruta montana). It has been used to ward off and cure the evil eye in the form of humaza (smoking) (Gallego and Gallego 2008: 110), and to frighten off witches by placing a small branch under the pillow or mattress, or in the kitchen llares (the iron chain in the fireplace from which cauldrons were hung) to repel the possible entry of witches through the chimney, or on the front door to prevent their entry, "because witches cannot abide its smell" (Panero 2005: 120; Gallego and Gallego 2008: 77). Children would carry a small bag containing the plant hidden in their clothes.

At Pereña de la Ribera (Salamanca), houses were protected by hanging a plant known as anda tú behind the door. This name stems from the popular belief that, when the plant is properly placed, the witch, when trying to get into the house, would say "Anda tú, que yo no puedo" (lit. Come into [the house], because I can't) (Blanco 1992: 163). According to Blanco it is probably Sisymbrium officinale, but we have not been able to confirm this. In other villages garlic — "the greatest enemy of witches" — was used as a repellent and strings of garlic were hung on doors (Fig. 4) (Blanco 1992: 163; Panero 2005: 126). Finally, in some villages of the Arribes del Duero in the 


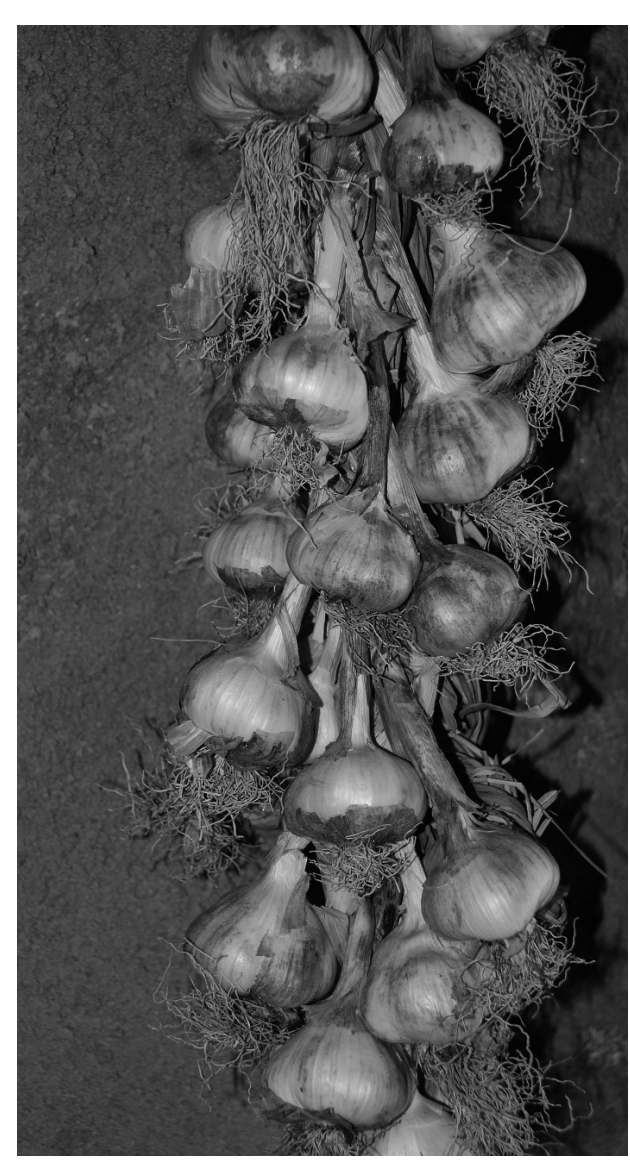

FIGURE 4: The garlic was used as a witch repellent, and strings of garlic were hung on doors. province of Zamora, the cane known as hierbatú (Peucedanum officinale) was used as a repellent against witches (Cortés Vázquez 1995: 158; Panero 2005: 102), and even today Dracunculus vulgaris is grown in some home-gardens (Panero 2005: 124).

\section{CONClusions}

Unlike other zones studied in Spain (e.g. Baer et al. 2006: 145; Grau García 2008: 39-43; Vallejo et al. 2008: passim), in the Arribes del Duero the plant component of rituals aimed at the prevention and cure of the evil eye has been hugely important in their recent history.

In the literature review found references to traditional use of plants as repellents of witches and plants which are the main element in rituals of curing and protection of people and animals. Were also found data relating to the protection of certain possessions, including houses and stables.

\section{LITERATURE CITED}

Baer, R. D., S. C. Weller, J. C. González, and J. Feria. 2006. "Las enfermedades populares en la cultura española actual: un estudio comparado sobre el mal de ojo". Revista de Dialectología y Tradiciones Populares 61: 139-156.

Blanco, J. F. (dir.). 1985. Prácticas y creencias supersticiosas en la provincia de Salamanca. Salamanca: Diputación de Salamanca.

Blanco, J. F. 1992. Brujería y otros oficios populares de la magia. Valladolid: Ámbito.

Blanco, J. F. 2009. "Identidades ajenas al tiempo", in V. Sierra Puparelli, A. Colinas, J. A. Pascual and J. F. Blanco (eds.), Arribes del Duero. Tierra de limites: 49-65. Salamanca: Diputación de Salamanca. 
Campagne, F. A. 2008. "Witch or demon? Fairies, vampires, and nightmares in Early Modern Spain". Acta Ethnographica Hungarica 53: 381-410.

Castroviejo, S. (coord.). 1986-2010. Flora iberica. Plantas vasculares de la Península Ibérica e Islas Baleares. Vols. I-VIII, X, XII-XV, XVII-XVIII, XXI. Madrid: Real Jardín Botánico - CSIC.

Cortés Vázquez, L. L. 1955. "Brujas en Villarino". Monterrey 1: 13-16.

Cortés Vázquez, L. L. 1995. Donde Sayago termina... Fermoselle. Salamanca: Librería Cervantes (2nd edition).

Fernández Álvarez, M. D. and J. Breaux. 1998. Medicina popular, magia y religión en El Bierzo. Ponferrada: Museo del Bierzo-Ayuntamiento de Ponferrada.

Fernández de Gatta, A. G. 1951. "El mal de ojos en los niños". Hoja folklórica 6: 24. Centro de Estudios Salmantinos, Salamanca, Spain (facsimile edition by Ángel Carril, 1995).

Gallego, E. and A. Gallego. 2008. Usos, tradiciones y conocimiento de las plantas por las gentes de Sayago. Bermillo de Sayago (Zamora): ADERISA.

González, J. A. 2010. "Brujas en comunidades rurales: identidad, poderes y narraciones en un "pueblo de brujas" del centro-occidente español". Revista de Folklore 348: 183-187.

González, J. A., M. García-Barriuso, and F. Amich. 2010. "Ethnobotanical study of medicinal plants traditionally used in the Arribes del Duero, western Spain". Journal of Ethnopharmacology 131 (2): 343-355.

Granzow de la Cerda, I. (ed.). 1993. Etnobotánica: el mundo vegetal en la tradición. Salamanca: Diputación de Salamanca.

Grau García, N. 2008. "El agua y la medicina popular en el campo de Cartagena: terapia 'catártica' y purificadora”. Revista Murciana de Antropología 15: 35-51.

Hernández, J. M. 1953. "Sobre brujas". Hoja folklórica 96: 381. Salamanca: Centro de Estudios Salmantinos (facsimile edition by Ángel Carril, 1995).

Lamano, J. de 1915. El dialecto vulgar salmantino. Salamanca: Diputación de Salamanca (facsimile edition, 2008).

Morán, C. 1927. "Creencias sobre curaciones supersticiosas recogidas en la provincia de Salamanca". Actas y Memorias de la Sociedad Española de Antropología, Etnografía y Prehistoria 6: 241-261.

Morán, C. 1946. Reseña histórico-artística de la provincia de Salamanca. Valladolid: Universidad de Salamanca (facsimile edition by Diputación de Salamanca, 2000).

Narros, V. H. 1951. "El mal de ojo, el arrayado de las calenturas y las cuerdas torcidas". Hoja folklórica 1: 3-4. Centro de Estudios Salmantinos, Salamanca (facsimile edition by Ángel Carril, 1995).

Panero, J. A. 2005. Sayago, costumbres, creencias y tradiciones. Bermillo de Sayago (Zamora): ADERISA (2nd edition).

Pardo de Santayana, M. 2008. Estudios etnobotánicos en Campóo (Cantabria). Conocimiento y uso tradicional de plantas. Madrid: CSIC.

Pascual, J. A. 2009. "Por el Duero de Portugal y España", in V. Sierra Puparelli, A. Colinas, J. A. Pascual and J. F. Blanco (eds.), Arribes del Duero. Tierra de límites: 35-47. Salamanca: Diputación de Salamanca.

RAE (Real Academia Española) 2010. Diccionario de la Lengua Española (22nd edition). http://buscon.rae.es/draeI

Tutin, T., V. Heywood, A. Burges, D. Valentine, D. Moore, M. Walters, and D. Webb (eds.). 1964-1993. Flora Europaea. Vols. 1-5. Cambridge (UK): Cambridge University Press. 
Vallejo, J. R., D. Peral, and M. C. Carrasco. 2008. "Prácticas mágicas en la medicina popular de un pueblo extremeño de colonización". Gazeta de Antropología 24: 24-32.

Verde, A., D. Rivera, and C. Obón. 1997. "Plantas mágicas de la provincia de Albacete: maléficas, protectoras y mágico-curativas". Al-Basit 40: 143-156.

Fecha de recepción: 12 de marzo de 2010

Fecha de aceptación: 11 de abril de 2011 